\title{
STUDY ON THE CALCIUM ROLE IN PROPRANOLOL-VERAPAMIL INTERACTION ON THE KIDNEY
}

\author{
By \\ W.M. El-Kholy; Th. Fayed; \\ z.M. El-Gohary and S.M. Sirag* \\ From \\ Zoology Department, Faculty of Science and *Pathology Department, \\ Faculty of Medicine, Mansoura University. \\ Received for puplication : 1712/1991
}

\section{INTRODUCTION}

Propranolol, a drug which has both beta-1 and beta-2 adrenoceptor antagonistic action which plays an important role in the function of the heart (Ichihara et al., 1979; and Pieper et al., 1980), is widely used in the treatment of hypertension (Lewis and Haeusler, 1975; Privitera et al., 1979; and O'Connor and Richard, 1982). It was found also to reduce the renal blood flow and glomerular filteration rate (O'Connor and Richard, 1982) and suppress renin release (Buhler et al., 1972; Privitera et al., 1979; and Kida et al., 1985).

Verapamil, a calcium channel 219 blocking agent, originally introduced for the treatment of myocardial ischaemia (Sandler et al., 1968; and Sowton, 1969), has been shown to have antiarrhythmic properties (Schamroth et al., 1972) and antihypertensive effect which was the greatest in lower renin groups (Nicholson et al., 1987).

Because of the increasing use of propranolol and verapamil in combination, a study of their interaction was important. Kandil et al., 1981 and 1983 reported that simuptaneous administration of propranolol and verapamil is toxic to the experimental animals. These drugs evidently induce their toxic interaction through the blockade of Ca-channels.

MANSOURA MEDICAL JOURNAL 
Therefore this study aims to investigate the effect of the concomitant administration of propranolol and verapamil on the renal function, and morphology and the possible role of calcium supplementation.

\section{MATERIALS AND METHODS}

Male white Wister rats weighing about $190 \mathrm{~g}$ were used in this study. The animals were arranged in five different groups; the control (given saline solution), propranolol $(P)$ treated animals (100 mg/kg b.w.), verapamil (V) treated rats $(80 \mathrm{mg} / \mathrm{kg}$ b.w.), propranolol + verapamil $(P+V)$ treated rats, and propranolol + verapamil + $\mathrm{CaC} 12$ $(\mathrm{P}+\mathrm{V}+\mathrm{Ca})(300 \mathrm{mg} / \mathrm{kg} \mathrm{b.w}$ ) $)$ treated animals. All drugs were dissolved in saline solution and were given daily by the gastric intubation for four weeks.

Blood, urine and tissue samples were collected 24 hours after last treatment. Serum and urine electrolytes $(\mathrm{Na}, \mathrm{K}, \mathrm{Ca}$ ) were determined using flame photometer (Jenway, 8505. PFP7). Serum urea and creatinine were estimated by enzymatic colorimetric method using biomerieux kits.
Renal Na-K-ATPase activity was measured according to Bonting et al., 1961 technique. Nephrons were numerated using the method of Damadian et al., 1965. After weighing the right and left kidneys, parts of them were fixed in $10 \%$ neutral formalin and processed as paraffin sections. These were stained with haematoxylin and eosin for histopathological examination. Another fresh parts were taken for preparing cryostate sections for histochemical demonstration of lipids (oil Red $O$ stain).

\section{RESULTS}

Fig. (1) illustrates a reduction in the percentage change of the mean total body weight gain of the treated groups comparing to the control in the following order: $\mathrm{P} .+\mathrm{V}>\mathrm{P} .+\mathrm{V} .+\mathrm{Ca}>\mathrm{V} .>$ $P$.

The absolute and relative weights of the right and left kidneys, and also the number of nephrons were decreased in all treated animals (Table $1)$. This decrease was more pronounced in P.+V. treated group. $\mathrm{CaC} 12$ administration improved the 
changes which induced by the concomitant treatment of $P .+V$.

Table (2), shows significant decrease in serum $\mathrm{Na}$ and urinary $\mathrm{K}$ concentrations, while serum $\mathrm{K}$ and $\mathrm{Ca}$; urinary $\mathrm{Na}$ and $\mathrm{Ca}$; and urinary $\mathrm{Na} / \mathrm{K}$ ratios were increased significantly. The changes were more obvious in P.+V. treated rats. Administration of $\mathrm{CaC} 12$ reduced some changes which induced by $P .+V$.

Serum concentrations of urea and creatinine were significantly increased specially in P.+V. treated group. This increase was diminished by $\mathrm{CaC} 12$ administration ( $P>0.01)$. Meanwhile Na-K-ATPase activity was decreased significantly in the renal tissues of all treated groups specially $P .+V$. treated group.

Histopathological examination of the kidneys of $\mathrm{V}$. treated group revealed tubular cells degenerations in the form of cloudy swelling and vacuolations (Fig. 2). Oil red O stain was -ve for fat deposition in this group. In $P$. treated group, in addition to the tubular cells degenerations, focal interstitial mononuclear cells infiltration was seen oil red $O$ staining for fat was + ve with mild intensity(+) (Fig. 3).

Kidneys of P.+V. treated rats showed both glomerular and tubular changes. Some glomeruli appeared atrophic and small in size with associated periglomerular fibrosis. Others showed hypertrophy and increase in size (Fig. 4). The tubules revealed degenerative changes in the form of cloudy swelling, vacuolation (Fig. 5) and fatty changes(Oil red o stain was +ve with moderate (++) intensity)(Fig. 6). Focal tubules showed atrophy of their epithelial lining (Fig. 7). Interstitial nephritis as well as focal fibrosis were present.

In $\mathrm{P} .+\mathrm{V} .+\mathrm{CaC} 12$ treated group, the previous histopathological changes disappeared and mild cloudy swelling of the proximal convoluted tubules was the only detectable change.

\section{DISCUSSION}

The results of this study exhibited a marked reduction in the percentage MANSOURA MEDICAL JOURNAL 
change of the mean body weight gain in all treated groups. Our results are in accordance with prior observations which recorded a significant reduction in the body weight gain in propranolol treated animals compared to control in both sexes (Donta et al., 1982) Conversely other reports failed to find any effect on the body weight in propranolol treated patients $\left(\mathrm{O}^{\prime}\right.$ Connor and Richard, 1982) or mice (Dulloo and Miller, 1985).

The absolute and relative weights of both the right and left kidneys in the treated groups were also decreased, with subsequent decrement in the number of nephrons per $\mathrm{mg}$ of the kidney tissue. Donta et al., 1982 showed lowered organ weights in propranolol treated rats except for the kidneys of both sexes and the heart and testes of the males. Such differences may be related to the time of treatment and the age of used animals.

Renal Na-K-ATPase activity was reduced by propranolol and/or verapamil. Such results can explain the raised sodium $(\mathrm{Na})$ concentrations in the urine of these groups, where a close correlation has been found between the reduction in Na-K-ATPase activity in post obstructive rat kidney and the changes in filtered $\mathrm{Na}$ load, and tubular reabsorption (Wilson et al., 1974). Subsequently the elevation in the urinary $\mathrm{Na}$ concentrations can explor its decrement in the sera of these groups. Moreover propranolol was found to diminish mineralocorticoids specially aidosterone and impair sodium excretion (O'Connor and Richard, 1982).

Potassium levels were increased in the sera of the animal treated with propranolol and/or verapamil. Such increment may be attributed to decreased giomerular filteration rate (GFR) which was recorded previously in propranolol treated hypertensive patients $\left(O^{\prime}\right.$ Connor and Richard, 1982), besides the reducing action of the drug on aldosteronewhich is responsible for $\mathrm{K}$ excretion by the distal convoluted tubules.Moreover these informations may also explain the declined urinary $\mathrm{K}$ concentration and the elevated urinary $\mathrm{Na} / \mathrm{K}$ ratios in these 
groups.

Calcium was found to be increased in the sera of all treated groups, and was higher in rats receiving $P .+V$. than in those receiving other drugs. The profound increase in serum calcium may be related to inhibition of calcium transport from blood through its specific channels (Kandil et al., 1983). The rise in serum calcium levels lead to their elevation in urine.

Serum concentrations of urea and creatinine were elevated also in propranolol and/or verapamil treated animals. Such results which reflects the disturbance in the renal function as shown in the work of lbsen and Sederberg-Olsen, 1973; Falch et al., 1978; and O'Connor and Richard, 1982, who found declines in (GFR); renal blood flow (RBF); and renal plasma flow (RPF), but without any change in the usual serum indices of renal function (BUN and creatinine) (O'Connor and Richard, 1982).

The histopathological changes in $P, V$ and $P+V$ groups were mainly tubular, in the form of tubular degeneration (cloudy swelling and vacuolations). Moreover fatty deposition was present in both $\mathrm{P}$ and $\mathrm{P}+\mathrm{V}$ groups only. These renal changes may be attributed, to decrease in renal Na-KATPase under the influence of propranolol and/or verapamile (Williams and Fanstil, 1970). The additional fatty change in renal tubules found in group $P$ and group $P+V$ may be related to disturbed phospholipid metabolism induced by propranolol ( Pappu and George, 1982).

Glomerular damage was also detected, in addition to tubular change, in group $P+V$ only. It was in the form of focal atrophy with periglomerular fibrosis, associated by focal interstitial nephritis and fibrosis. Some glomeruli appeared, on the other hand, hypertrophic and large sized. The detected glomerular atrophy and periglomerular fibrosis may, be part of the focal nephritis demonstrated in the same group of rats. The large sized glomeruli found in rats of this group may represent a form of compensatory hypertrophy of these glomeruli in response to

MANSOURA MEDICAL JOURNAL 
atrophic ones.

A striking feature in this study was that addition of calcium to P.+V. prevented the previously mentioned changes, this finding represent a support to previous studies recording that $P ., V$. interaction is induced via blockage of calcium channels (Kandil et al., 1981).

In conclusion, the authors suggested that simultaneous administration of propranolol and verapamil should be used cautiously, and recommended that calcium can be used to reduce their synergistic toxicity.

\section{SUMMARY}

The results showed decreases in the percentage change of the mean body weight gain, absolute and relative kidney weights, and the number of nephron in both the right and left kidneys of propranolol (P.) and/or verapamil ( V. ) treated rat groups. Moreover significant decreases were shown in serum $\mathrm{Na}$, urinary $\mathrm{K}$, and renal $\mathrm{Na}$ K-ATPase activity; while significant increase was illustrated in serum $\mathrm{K}$ and $\mathrm{Ca}$; urinary $\mathrm{Na}$ and $\mathrm{Ca}$; and serum urea and creatinine of the same groups. The changes were more obvious in the group treated with $(P .+V$.$) in$ combination. Administration of calcium chioride $\left(\mathrm{CaC}_{12}\right)$ minimized these effects.

Histopathological and histochemical examination revealed tubuiar epithelial degenerations in either $P$ or $V$ groups and accompanied by glome $u$ lar changes and interstitial nephritic in the group given combined $P+V$. The previous lesions were diminished after calcium supplementation.

These results ensure the adverse effects of the combined use of these drugs on the kidney, and deduce that calcium supplementation may reduce these changes but does not prevent them completely.

Volume 21, 1991 
Table 1. Absolute ( $\mathrm{mg}$ ), and relative weights $(\mathrm{mg} / 100 \mathrm{~g}$ body $w \mathrm{t})$ ' and the number of nephrons ( number/mg wet kidney) of the right (R.) and left kidneys in the control and treated animal groups.

\begin{tabular}{|c|c|c|c|c|c|c|c|}
\hline & & \multicolumn{2}{|c|}{ Absolute wt. } & \multicolumn{2}{|c|}{ Relative wt. } & \multicolumn{2}{|c|}{ Number of nephron } \\
\hline & & R. & L. & R. & L. & R. & L. \\
\hline Con. & Mean \pm SE & $825.4 \pm 5.70$ & $800 \pm 2.06$ & $449 \pm 2.55$ & $435.6 \pm 1.56$ & $25.2 \pm 0.52$ & 21. $2 \pm 0.52$ \\
\hline P. & $\begin{array}{l}\text { Mean } \pm S E \\
\& \text { of changc } \\
\text { P. value }\end{array}$ & $\left|\begin{array}{c}810.6 \pm 1.08 \\
-1.79 \\
<0.05\end{array}\right|$ & $\begin{array}{c}755.4 \pm 1.37 \\
-5.78 \\
<0.005\end{array}$ & $\begin{array}{c}408 \pm 2.64 \\
-313 \\
<0.005\end{array}$ & $\mid \begin{array}{c}380.2 \pm 2.37 \\
-12.72 \\
<0.005\end{array}$ & $\begin{array}{c}23.0 \pm 0.63 \\
-8.73 \\
<0.05\end{array}$ & $\begin{array}{c}20.0 \pm 0.4 \\
-5.66 \\
\text { N.s. }\end{array}$ \\
\hline v. & $\begin{array}{l}\text { Mean } \pm S E \\
\& \text { of changd } \\
P \text { - value }\end{array}$ & $\mid \begin{array}{c}803.6 \pm 1.61 \\
-2.64 \\
<0.005\end{array}$ & $\begin{array}{c}792.2 \pm 1.04 \\
-0.98 \\
<0.005\end{array}$ & $\mid \begin{array}{c}396.8 \pm 2.46 \\
-11.63 \\
<0.005\end{array}$ & $\mid \begin{array}{c}391.2 \pm 3.34 \\
-10.19 \\
<0.005\end{array}$ & $\begin{array}{c}23.6 \pm 0.46 \\
-2.35 \\
<0.05\end{array}$ & $\begin{array}{c}20.4 \pm 0.46 \\
-3.77 \\
\text { N.s. }\end{array}$ \\
\hline P.+V. & $\begin{array}{l}\text { Mean } \pm \text { SE } \\
\& \text { of changc } \\
\text { P- value }\end{array}$ & $\begin{array}{c}796 \pm 1.41 \\
-3.56 \\
<0.005 \\
\end{array}$ & $\mid \begin{array}{c}755.4 \pm 1.37 \\
-5.78 \\
<0.005 \\
\end{array}$ & \begin{tabular}{|c|}
$371.4 \pm 2.84$ \\
-17.28 \\
$<0.005$ \\
\end{tabular} & $\begin{array}{c}349.4 \pm 3.42 \\
-19079 \\
<0.005 \\
\end{array}$ & $\begin{array}{c}18.8 \pm 0.33 \\
-25.40 \\
<0.05 \\
\end{array}$ & $\begin{array}{c}18.6 \pm 0.46 \\
-12.26 \\
<0.005\end{array}$ \\
\hline $\begin{array}{c}\mathrm{P}+\mathrm{V} .+ \\
\mathrm{Cach}\end{array}$ & $\mid \begin{array}{l}\text { Mean } \pm S E \\
\& \text { of changc } \\
P \text { - value }\end{array}$ & $\mid \begin{array}{c}814.2 \pm 1.43 \\
-1.36 \\
\text { M.S }\end{array}$ & \begin{tabular}{|c}
$748.8 \pm 1.15$ \\
6.4 \\
$<0.005$
\end{tabular} & $\begin{array}{c}438.4 \pm 3.56 \\
-2.36 \\
<0.005\end{array}$ & $\begin{array}{c}423.6 \pm 2.54 \\
-2.75 \\
<0.005\end{array}$ & $\begin{array}{c}24.4 \pm 0.46 \\
-3017 \\
\text { N.S. }\end{array}$ & $\begin{array}{c}20.8 \pm 0.33 \\
-1.89 \\
\text { M. S. }\end{array}$ \\
\hline
\end{tabular}

Table 2. Serum and urinary concentrations of electrolytes in ( $\mathrm{mmol} / \mathrm{L}$ ); and urinary $\mathrm{Na} / \mathrm{k}$ ration in control and treated animal groups.

\begin{tabular}{|c|c|c|c|c|c|c|c|c|}
\hline & & \multicolumn{3}{|c|}{ Serum } & \multicolumn{3}{|c|}{ Urine } & \multirow{2}{*}{ L. } \\
\hline & & $\mathrm{Na}$ & K & Ca. & L. & R. & L. & \\
\hline Con. & Mean \pm SE & $137 \pm 0.63$ & $3.64 \pm 0.08$ & $2.44 \pm 0.05$ & $12.6 \pm 0.46$ & $16.4 \pm 0.46$ & $0.64 \pm 0.004$ & $0.77 \pm 0.01$ \\
\hline P. & $\left|\begin{array}{l}\text { Mean } \pm S E \\
\& \text { of changc } \\
P \text { : value }\end{array}\right|$ & \begin{tabular}{|c|}
$132.0 \pm 0.63-$ \\
10.95 \\
$<0.05$
\end{tabular} & $\begin{array}{c}408 \pm 0.03 \\
+12.09 \\
<0.005\end{array}$ & $\begin{array}{c}3.44 \pm 0.09 \\
+40.98 \\
<0.005\end{array}$ & $\begin{array}{c}17.0 \pm 0.63 \\
+34.92 \\
<0.005\end{array}$ & $\begin{array}{c}14.4 \pm 0.46 \\
-12.20 \\
<0.05\end{array}$ & $\begin{array}{c}0.76 \pm 0.04 \\
+18.75 \\
<0.05\end{array}$ & $\begin{array}{c}1.18 \pm 0.04 \\
+53.25 \\
<0.005\end{array}$ \\
\hline V. & $\begin{array}{l}\text { Mean } \pm S E \\
\& \text { of changd } \\
P \text { - value }\end{array}$ & $\mid \begin{array}{c}112.8 \pm 0.77 \\
-17.66 \\
<0.005\end{array}$ & $\begin{array}{l}4.0 \pm 0.6 \\
+9.89 \\
<0.005\end{array}$ & $\begin{array}{l}3.0 \pm 0.06 \\
+22.95 \\
<0.005\end{array}$ & $\begin{array}{c}19.6 \pm 0.46 \\
+55.56 \\
<0.005\end{array}$ & $\begin{array}{c}14.6 \pm 0.22 \\
-10.98 \\
<0.005\end{array}$ & $\begin{array}{l}0.82+0.03 \\
+28.13 \\
<0.005\end{array}$ & $\begin{array}{l}1.32 \pm 0.02 \\
+71.45 \\
<0.005\end{array}$ \\
\hline $\mathrm{P} .+\mathrm{V}$. & $\begin{array}{l}\text { Mean } \pm S E \\
\& \text { of changc } \\
\text { P- value }\end{array}$ & $\begin{array}{c}103.2 \pm 1.12 \\
-24.82 \\
<0.005\end{array}$ & $\begin{array}{c}4.74+0.08 \\
+30.22 \\
<0.005 \\
\end{array}$ & $\begin{array}{r}4.8 \pm 0.17 \\
+96.72 \\
<0.005 \\
\end{array}$ & $\begin{array}{c}21.6 \pm 0.46 \\
+71.43 \\
<0.005 \\
\end{array}$ & $\begin{array}{c}12.2 \pm 0.33 \\
-25.61 \\
<0.05 \\
\end{array}$ & $\begin{array}{l}0.92_{ \pm} 0.03 \\
+43.75 \\
<0.005 \\
\end{array}$ & $\begin{array}{l}1.77 \pm 0.02 \\
+129.87 \\
<0.005 \\
\end{array}$ \\
\hline $\begin{array}{l}\mathrm{P} .+\mathrm{V} .+ \\
\mathrm{Cacl}_{2}\end{array}$ & $\mid \begin{array}{l}\text { Mean } \pm S E \\
\& \text { of changc } \\
\text { P-vaiue }\end{array}$ & $\begin{array}{c}125.8 \pm 1.43 \\
-8.18 \\
<0.005\end{array}$ & $\begin{array}{c}3.96 \pm 0.08 \\
+8.79 \\
<0.01\end{array}$ & $\begin{array}{c}2.56 \pm 0.05 \\
+4.92 \\
\text { N.S. }\end{array}$ & $\begin{array}{c}15.0 \pm 0.63 \\
+19.05 \\
<0.01\end{array}$ & $\begin{array}{c}14.6 \pm 0.46 \\
-10.98 \\
<0.01\end{array}$ & $\begin{array}{c}0.74 \pm 0.05 \\
+15.63 \\
\text { N.S. }\end{array}$ & $\begin{array}{c}1.05+0.01 \\
+33.77 \\
<0.005\end{array}$ \\
\hline
\end{tabular}


Table 3. Serum concentrations of urea and creatinine in ( $\mathrm{mg} / 100 \mathrm{m1}$ ); and renal $\mathrm{Na}-\mathrm{K}$ - ATPasc activity ( $\mathrm{umol} \mathrm{pi} / \mathrm{g} / \mathrm{mi}$ ) in control and treated animal groups.

\begin{tabular}{|c|c|c|c|c|c|c|}
\hline & & Cont. & L. & R. & L. & R. \\
\hline $\begin{array}{c}\text { Serum } \\
\text { Urea }\end{array}$ & $\begin{array}{l}\text { Mean } n_{ \pm} S E \\
\& \text { of changc } \\
\text { P- value }\end{array}$ & $31.6 \pm 0.46$ & $\begin{array}{c}36.410 .46 \\
+15.19 \\
<0.005\end{array}$ & $\begin{array}{c}42.2 \pm 0.77 \\
+33.54 \\
<0.005\end{array}$ & $\begin{array}{c}48.410 .46 \\
+53.16 \\
<0.005\end{array}$ & $\begin{array}{c}33.8 \pm 0.52 \\
+6.96 \\
<0.01\end{array}$ \\
\hline $\begin{array}{c}\text { Serum } \\
\text { Creatinine }\end{array}$ & $\begin{array}{l}\text { Mean } \pm \text { SE } \\
\& \text { of changc } \\
\text { P-value }\end{array}$ & $0.45+0.009$ & $\begin{array}{c}0.49+0.006 \\
+8.89 \\
<0.005\end{array}$ & $\begin{array}{c}0.53+0.009 \\
+17.78 \\
<0.005\end{array}$ & $\begin{array}{c}0.75 \pm 0.01 \\
+66.67 \\
<0.005\end{array}$ & $\begin{array}{c}0.47 \pm 0.01 \\
+4.44 \\
\text { N.S. }\end{array}$ \\
\hline $\begin{array}{l}\text { Renal } \\
\text { Na - k- } \\
\text { ATPase }\end{array}$ & $\begin{array}{l}\text { Mean } \pm \text { SE } \\
\& \text { of changc } \\
\text { P. value }\end{array}$ & $10.04 \pm 0.1$ & $\begin{array}{c}9.3 \neq 0.09 \\
-7.37 \\
<0.005\end{array}$ & $\begin{array}{l}8.58 \pm 0.1 \\
-14.54 \\
<0.005\end{array}$ & $\begin{array}{l}7.96 \pm 0.05 \\
-20.72 \\
<0.005\end{array}$ & $\begin{array}{c}9.6 \pm 0.06 \\
-4.38 \\
<0.005\end{array}$ \\
\hline
\end{tabular}

$P$ - values indicate significant difference

N. S. : Not significant. Each group represents 5 male rats

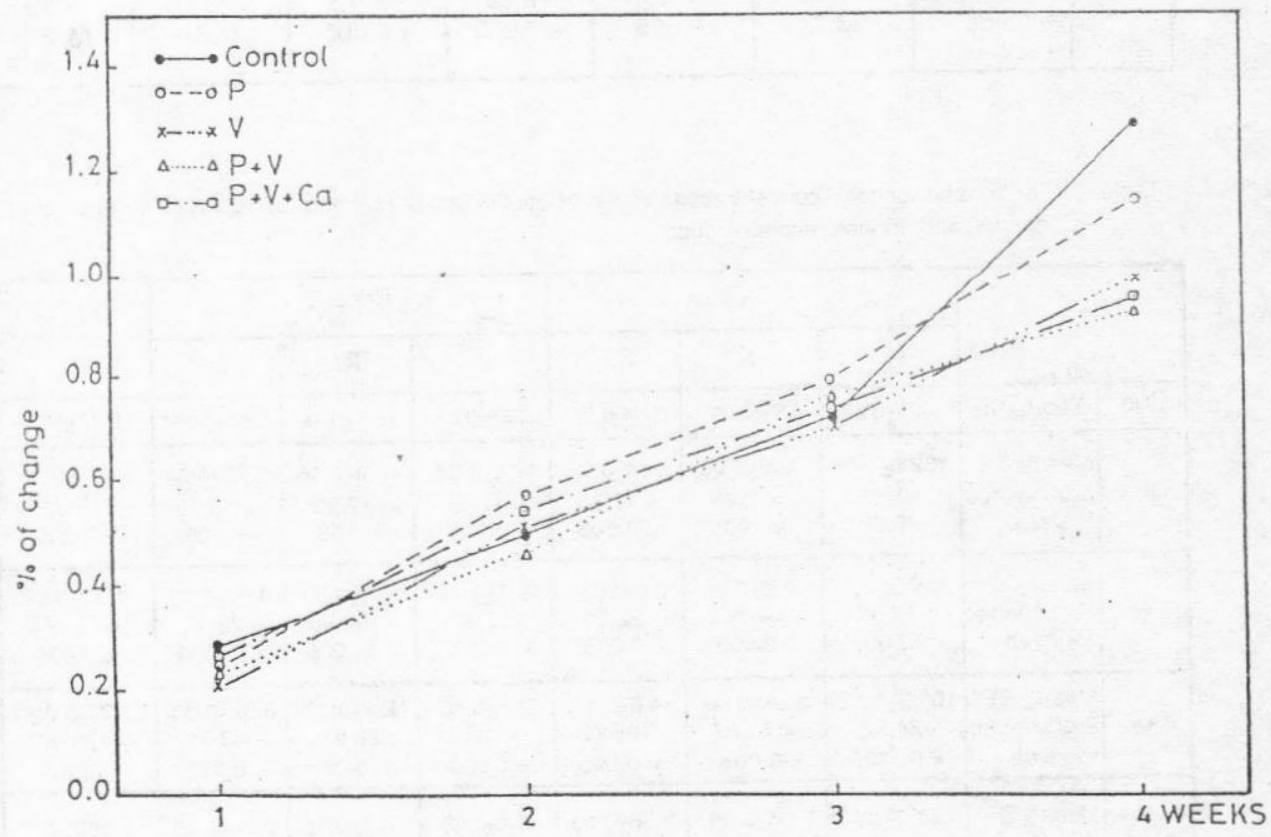

Fig. 1. Percentage change in the mean total body weight gain of control and treated rats.

Volume 21, 1991 


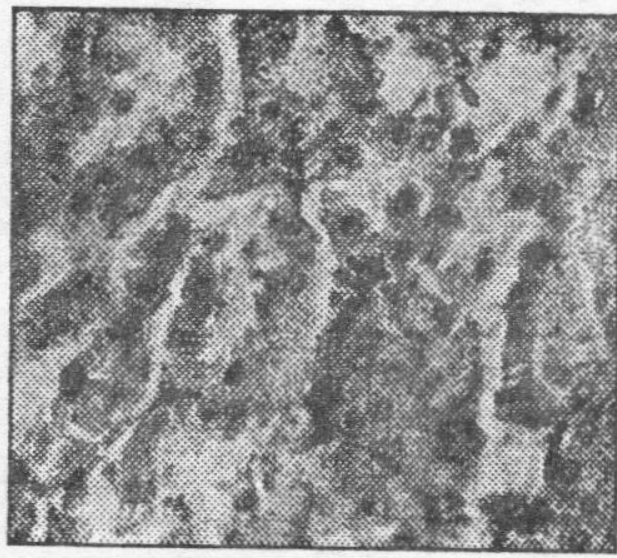

Fig. 2. Section of kidney of rat received verapamil showing cloudy swelling and vacuolation of tubular epithelium $(\mathrm{Hx}$ \& Es, $x$ 400).

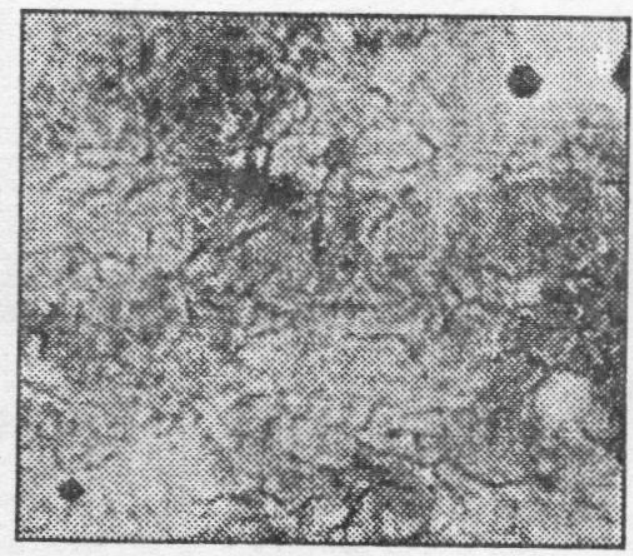

Fig. 3. Section of kidney of rat received propranolol showing mild degree of fat accumulation (oil red $0, \times 250$ ).

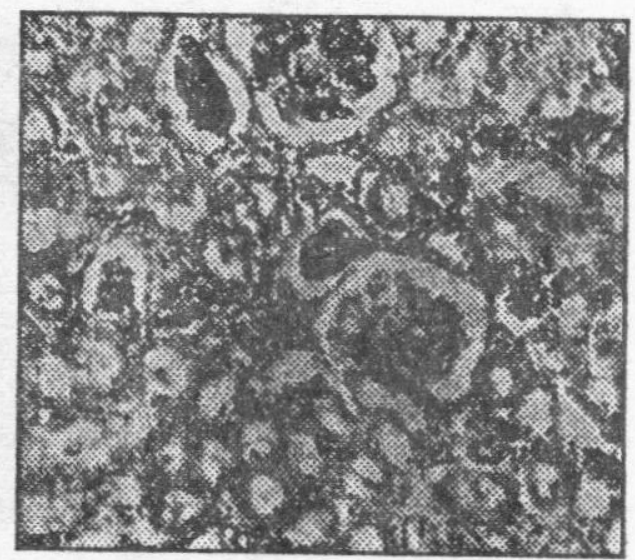

Fig. 4. Section of kidney of rat recieved verapamil and propranolol showing atrophic glomeruli and periglomerular fibrosis. (Hx \& Es $\times 250)$.

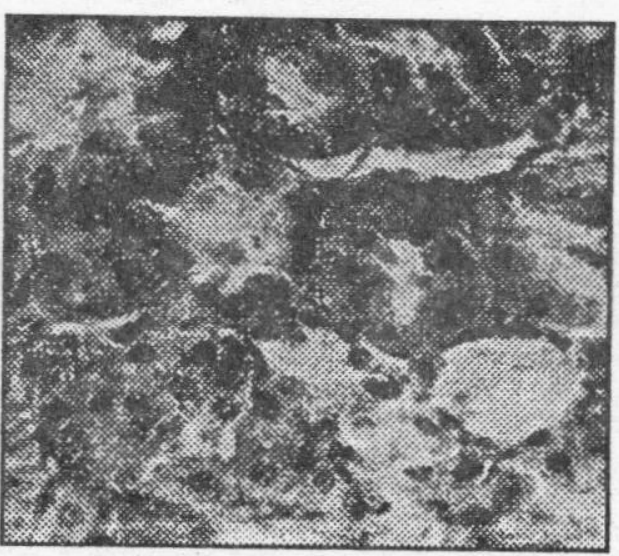

Fig. 5. Section of kidney of rat recieved verapamil and propranolol showing cloudy swelling of the tubular epithelium ( $\mathrm{Hx} \& \mathrm{Es}, \mathrm{X} 400$ )

MANSOURA MEDICAL JOURNAL 


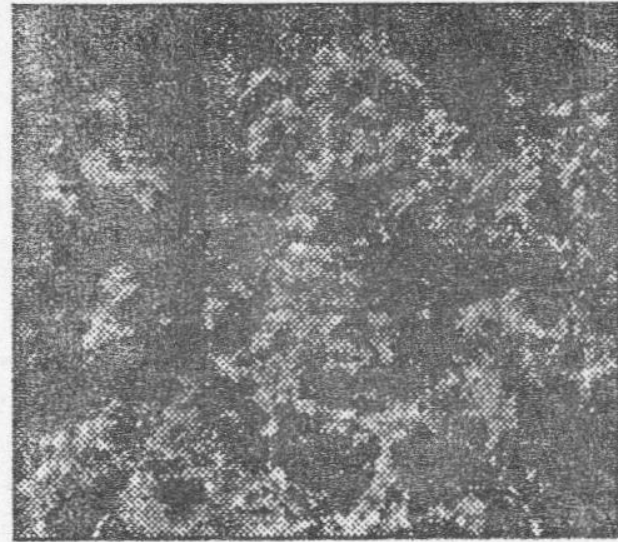

Fig. 6. Section of kidney of rat recieved verapamil and propranolol showing moderate degree of fat accumulation. (Oil red 0, X 250).

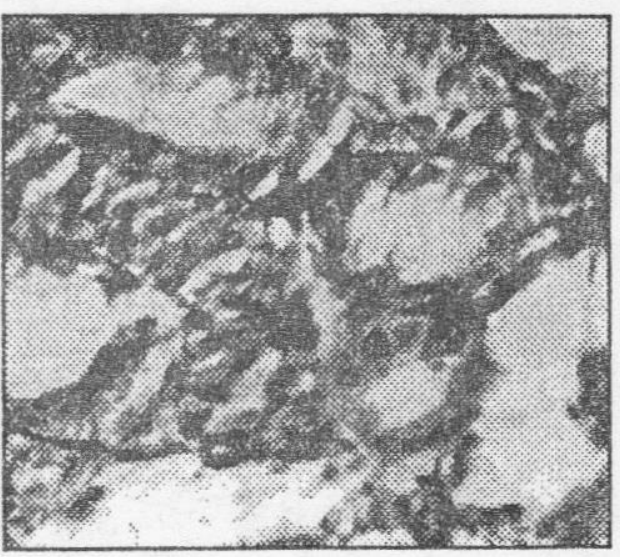

Fig. 7. Section of kidney of rat recieved verapamil and propranolol showing atrophy of the epithelial lining of some tubules (Hx \& Es, x 400). 


\section{REFERENCES}

Bonting, S. L.; Simon, K.A. and Ibsen H.; Sederberg-Olsen P. Hawkins, N, M. (1961) : (1973): Clin. Sci. $44: 129$.

Arch. Biochem. Biophys., 95, 416 - 421.

Ichihara $\mathrm{K}$; Ichihara $\mathrm{M}$, and Abiko Y. (1979): J.Pharmacol. Exp.

Buhler, F. R.; Laragh, J.H.; Baer,L.; Ther. 209: $275-281$.

Vaughn, E. D. and Brunner, H. R. (1972) : N.Engl. J. Med. $287: 1209$ - 1214.

Damadian, R.V.; Shawayri, E. and Bricker, N.S, (1965) : J. Kandil, A.; Vick J.; Herman L. and Balaz S.T. (1981) : J. Drug Res. Egypt, 13, 1-2, 13. Quoted from Kandil et al., 1983.

Lab. Clin. Med., 65, 26 - 39.

Donta, 1.; Karayannacos, P. E.; Boudoulas, H.; Kostakis, A.; Sechas, M.; Varonos, D. and Sealkeas, G. R. (1982): Res. Commun. Chem. Pathol. Pharmacol. 37 (1) : 147 150.

Kandil, A,; Said A.A. and Balaza, S. T. (1983) : J. Drug Res., Egypt, $14(1-2): 23-26$.

Kida Osamu; Yasuyuki Morotomi; Toshinobu Higa and Kenjiro Tanaka (1985) : Heart Vessels 1 (13) : $158-161$.

Dulloo, A.G. and Miller,D.S. (1985) : Lewis P.J. and Haeuslen G. (1975) : Metab. Clin. Exp. 34 (1) : Nature (London) $256: 440$. 1061 - 1065.

Nicholson J. P.; Resnick L. M. and Falch D.K.; Odegaard A,E. ; Norman Laragh J. H. (1987) : Ann. of N, (1978) : Scand. J. Clin. Lab. Invest. $38: 143$. Internal Medicine, 107: 3, 329-334. 
O'connor Daniel T. and Richard A. Preston (1982) : Hypertension (Dallas) 4 ( 5) : 742 749 .

Pappu, Anuradha S. and George Lausea A. (1982) : J. Pharmacol. Exp. Ther 222 (1) : $109-115$.

Pieper, G. M.; Todd, G. L.; Wu S.T.; Salhany J. M.; Glayton F. C. and Ellot R.S. (1980) : Williams R.D. and Fanestil D.D. Cardiovasc, Res. 14: 646 653.

Privitera P. J.; Webb J. G. and Walle T. (1979) : Eur. J. Pharma- Wilson D.R.; Knox W.; Hall E. and col. $5451-60$.

Sandler G.; Clayton G.A. and Thornicroft S.G. (1968) : British
Medical Journal, 3, 224. Quoted from Schamroth et al. 1972.

Schamroth L. ; Krikler D.M.; Garrett C. (1972): Bri. Med. J. , 1, $660-662$.

Sowton, E . (1969) : Prescriber's Journal 9, 79. Quoted from Schamroth et al., 1972. (1970) : Abstracts of American Society of Nepirology. Sen A.K. (1974) : Can. J. Physiol. Pharmacol., 52, 105-113. 


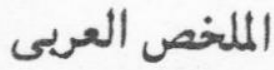

دراسة للدور الكالسيوم فى تأثير التداخل الدوائى

للبروبرانولول والفيراباميل على الكلية

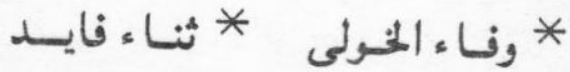

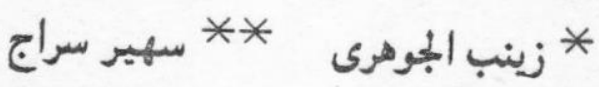

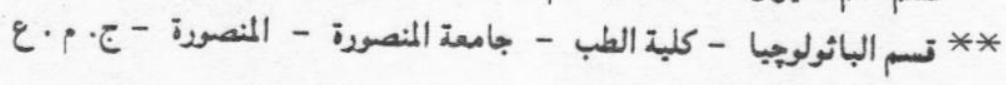

اجرى هذا البحث بهدف دراسة تأثير التداخل الدوائى للبرويرانولول والنيرابامبل على الكلية ، والدور البرا

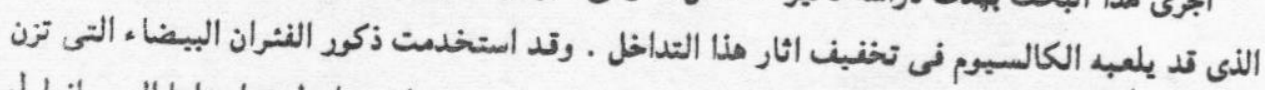

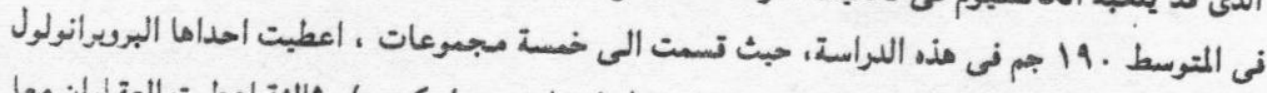

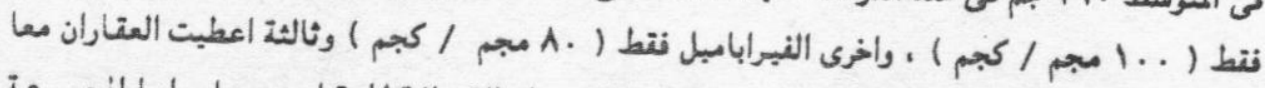

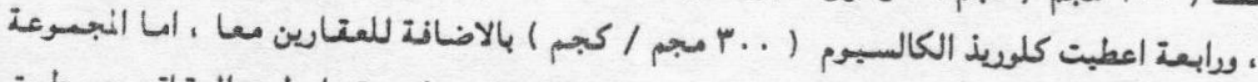

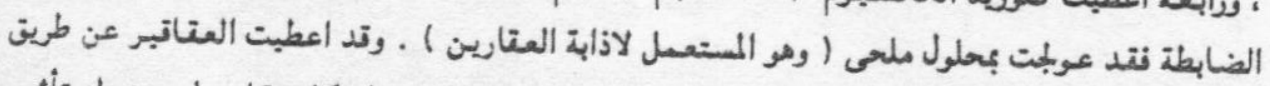

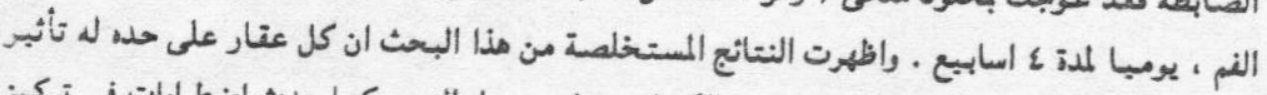

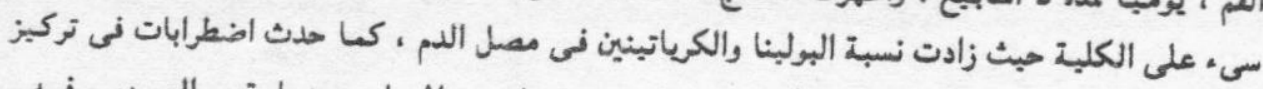

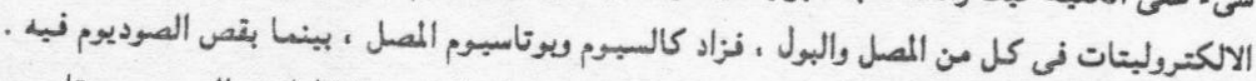

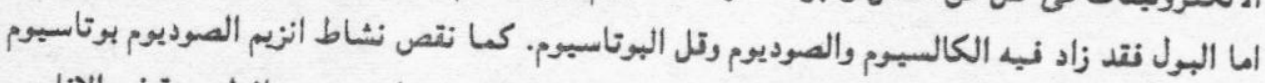

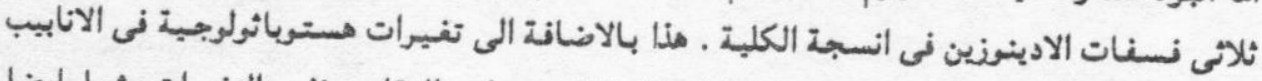

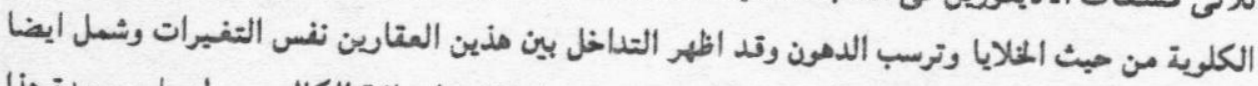

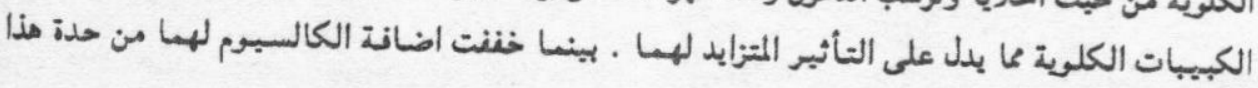
التأثير بلدرجة مقبولة . 
